\title{
舫 New Disease Reports \\ Occurence of Boeremia exigua var heteromorpha on Nerium oleander in the United Kingdom
}

B. Henricot

\author{
Department of Plant Pathology, The Royal Horticultural Society (RHS), Wisley, Woking, Surrey, GU23 6QB, UK \\ *E-mail: beatricehenricot@rhs.org.uk
}

Received: 13 Oct 2012. Published: 05 Nov 2012. Keywords: blight, leaf spot, fungal disease, Phoma

In August 2010, diseased samples of oleander (Nerium oleander) were received from the Plant Heritage National Plant Collection located in Devon, UK. Symptoms included leaf spots, stems lesions and dieback (Fig. 1). The disease was aggressive and a threat to the collection having affected $50 \%$ of the plants. Microscopic examination revealed the presence of irregularly scattered globose pycnidia associated with the necrotic lesions. The conidia were hyaline, mainly aseptate, occasionally one-septate, and measured 5.5-8.3 x 1.2-4.4 $\mu \mathrm{m}$ (average $6.5 \times 2.9 \mu \mathrm{m}$ ) (Fig. 2). A fungus was isolated on potato carrot agar (PCA) supplemented with ampicillin $(30 \mu \mathrm{g} / \mathrm{ml})$ and streptomycin sulphate $(133 \mu \mathrm{g} / \mathrm{ml})$. The mean daily radial increment was calculated based on values obtained from three isolates replicated three times. The growth rates were 8.3, 11.8 and $12.6 \mathrm{~mm} /$ day on malt extract agar (MA), oatmeal agar (OA) and PCA respectively at $22^{\circ} \mathrm{C}$ in the dark. A drop of concentrated $\mathrm{NaOH}$ at the margins of a 10-day-old MA culture produced a blue-green pigmentation that changed to red-brown, confirming production of antibiotic ' $E$ ' (derived from 'exigua') (Boerema et al., 2004) (Fig. 3). The ITS region was amplified using ITS1 and ITS4 primers (White et al., 1990) and sequenced (GenBank Accession No. JX467690). The sequence was identical to Boeremia (syn Phoma) exigua ITS sequences in GenBank (e.g. AY899262 $\&$ EU343168). There are two species of Phoma and related fungiaffecting Nerium, P. glaucispora and B. exigua var. heteromorpha. Based on the morphological and growth characteristics on agar (Boerema et al., 2004), sequencing and host, the pathogen was identified as B. exigua var heteromorpha. A voucher specimen was deposited at the Royal Botanic Gardens, Kew, UK (K(M) 173517).

To induce sporulation, the fungus was grown on water agar plates with sterilised buckwheat under near UV light $\left(16 \mathrm{~h}\right.$ photoperiod) at $22^{\circ} \mathrm{C}$. After seven days, pycnidia were collected and squeezed in sterile distilled water (SDW) to release the conidia. A conidial suspension $\left(1 \times 10^{4}\right.$ conidia/ml $)$ was used to spray-inoculate one four-year-old Nerium oleander 'Pink'. Another plant was inoculated by inserting $3 \mathrm{~mm}$ plugs of a seven-day-old culture into a slit made with a sterile scalpel on three stems. The plugs were moistened with SDW and wrapped in Parafilm. A plastic bag wa placed over all plants for $48 \mathrm{~h}$ to maintain high humidity and favour infection. The plants were kept in a polycarbonate growdome where the temperature was maintained at $20^{\circ} \mathrm{C}$ during the day and at $15^{\circ} \mathrm{C}$ during the night. The first leaf spots appeared five days post inoculation (dpi) on the plant that was spray-inoculated and a lesion was visible seven dpi on the stems inoculated with mycelial plugs (Fig. 4). Control plants sprayed with SDW and inoculated with sterile agar plugs did not develop any symptoms. Boeremia exigua var. heteromorpha was re-isolated from the leaf spot and stem lesion.

This is the first report of B. exigua var. heteromorpha on $N$. oleander causing leaf spot and dieback on oleander in the UK. Following this first report other cases were confirmed in West Midlands and Berkshire counties. This disease is known previously where Nerium is grown, including France, Italy, Spain and USA (Boerema et al., 2004; Álvarez et al., 2005).

\section{Acknowledgements}

The author would like to thank Ian Waghorn and Jenny Denton for their technical support and Plant Heritage for funding the research into this disease.

\section{References}

Álvarez LA, Armengol J, Pérez-Sierra A, León M, Abad P, Vicent A, García-Jiménez J, Beltrán C, 2005. First report of Phoma exigua var. heteromorpha causing oleander dieback in Spain. Plant Disease 89, 775. [http://dx.doi.org/10.1094/PD-89-0775B]

Boerema GH, de Gruyter J, Noordeloos ME, Hamers MEC, 2004. Phoma Identification Manual. Differentiation of specific and infra-specific taxa in culture. Wallingford, UK: CABI Publishing.

White TJ, Burns T, Lee S, Taylor J, 1990. Amplification and direct sequencing of fungal ribosomal genes for phylogenetics. In: Innis MA, Gelfand DH, Shinsky J, White TJ, eds. PCR protocols. A guide to methods and applications. San Diego, CA, USA: Academic Press, 315-322.

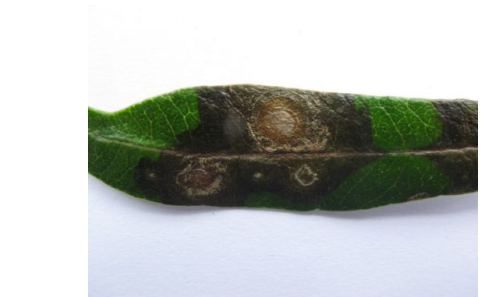

Figure 1

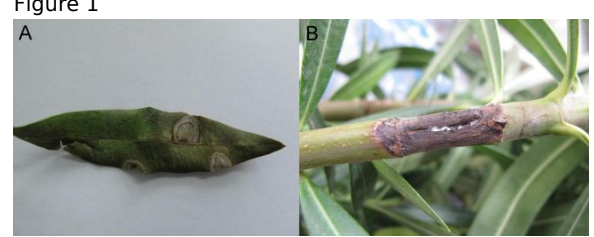

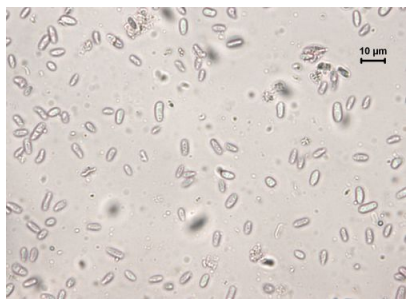

Figure 2

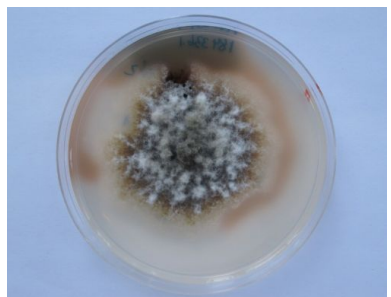

Figure 3

Figure 4

To cite this report: Henricot B, 2012. Occurence of Boeremia exigua var heteromorpha on Nerium oleander in the United Kingdom. New Disease Reports 26, 20. [http://dx.doi.org/10.5197/j.2044-0588.2012.026.020]

(c) 2012 The Authors

This report was published on-line at www.ndrs.org.uk where high quality versions of the figures can be found. 